J. Clin. Chem. Clin. Biochem.

Vol. 27, 1989, pp. 953-959

(C) 1989 Walter de Gruyter \& Co.

Berlin - New York

\title{
Simultaneous Quantification of Oestrogen and Progesterone Receptors by a Ligand Binding Assay in Frozen Sections
}

\author{
By G. Vollmer, Birgit Helmchen and R. Knuppen ${ }^{1}$ ) \\ Institut für Biochemische Endokrinologie, Medizinische Universität Lübeck, F.R.G.
}

(Received March 1/August 28, 1989

Summary: We describe two modifications of a double-isotope assay for measuring the concentrations of oestrogen receptors and progesterone receptors in tumour cytosols and extracts of frozen tumour sections and endometrial sections. The concentrations of these receptors are derived from single-point/isoelectric focussing assays after incubation of cytosols or section supernatants either with ([125I]vinyl)-nortestosterone and $\left[{ }^{3} \mathrm{H}\right]$ oestradiol or $\left[{ }^{125} \mathrm{I}\right]$ oestradiol and $\left[{ }^{3} \mathrm{H}\right] \mathrm{ORG} 2058$ (16 $\alpha$-ethyl-21-hydroxy-19-nor $\left[6,7^{3} \mathrm{H}\right]$ pregn-4-ene-3,20dione). The concentrations of the oestrogen and progesterone receptors found in cytosols $(r>0.93)$ and extracts from sections $(r>0.8)$ by dual label assays are highly correlated with those found by single label assays. The method described represents an approach to the determination of oestrogen and progesterone receptors biochemically in an amount of tissue which is comparable to that needed for immunocytochemical procedures.

\section{Introduction}

In human breast cancer, oestrogen and progesterone receptors represent an established determinant for their prognosis and serve as a guideline for their treatment. In view of the significantly longer survival times of patients with receptor-positive endometrial cancer (1), oestrogen receptor and progesterone receptor determinations provide useful prognostic data.

The most frequently applied method for the quantitation of the receptor content is the measurement of specific high affinity binding sites after incubation of tissue cytosols with radiolabeled receptor ligands (2, 3). During the last few years, antibodies directed against the oestrogen receptor (4) and progesterone receptor molecule (5) have been used either in immunocytochemical assays $(6-11)$ or in enzyme immunoassays (12-14).

1) This paper was supported by the Deutsche Forschungsgemeinschaft, Sonderforschungsbereich 232/A1.

2.) Abbreviation:

[3H]ORG $2058=16 \alpha$-ethyl-21-hydroxy-19-nor[6,7 $\left.{ }^{3} \mathrm{H}\right]$ pregn-

4-ene-3,20-dione
Conventional cytosolic ligand binding assays and enzyme immunoassays deliver quantitative results ( $\mathrm{fmol} /$ $\mathrm{mg}$ ), but at the expense of a relatively large amount of tissue. On the other hand, the immunocytochemical assay of frozen sections provides only semiquantitative scores of labelled cells, whereas enzyme immunoassays are expensive, especially if the number of specimen to be tested does not fit with the number of assays in the kit. In addition these kits have an upper limit for a given receptor concentration of an undiluted cytosol.

As an alternative, for a single receptor species (1517), we, like others, have recently developed an assay for both the determination of oestrogen receptor and progesterone receptor (18) in frozen sections of unfixed tumour tissue. To further minimize the amount of tissue needed, and to determine both receptor species quantitatively and simultaneously from the same set of frozen sections, we describe an assay in which sections are incubated in the presence of an iodinated gestagenic and tritiated oestrogenic ligand and vice versa, according to assays described for cytosols $(19-22)$. 


\section{Materials and Methods}

Endometrial tissue and endometrial carcinomas were obtained after hysterectomy, and human breast cancer specimens were obtained immediately after surgical removal. Samples suitable for either homogenisation or cryostat microtomy were trimmed of fat or necrotic tissue.

\section{Chemicals and buffers}

Radiolabelled ligands, $\left[2,4,6,7-{ }^{3} \mathrm{H}\right]$ oestradiol $(85-110 \mathrm{Ci} / \mathrm{mmol}$

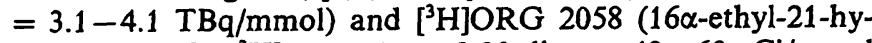
droxy-19-nor $\left[6,7^{3} \mathrm{H}\right]$ pregn-4-ene-3,20-dione; 40-60 Ci/mmol $=1.5-2.2 \mathrm{TBq} / \mathrm{mmol}$ ), as well as unlabelled ORG 2058 were purchased from Amersham (Braunschweig). [16 $\left.\alpha^{-125} \mathrm{I}\right]$ oestradiol $(200 \mathrm{Ci} / \mathrm{mmol}=7.4 \mathrm{TBq} / \mathrm{mmol})$ and $(\mathrm{Z})-17 \alpha-\left(\left[2{ }^{125} \mathrm{I}\right] \mathrm{vinyl}\right)-19-$ nortestosterone $(200-400 \mathrm{Ci} / \mathrm{mmol}=7.4-14.8 \mathrm{TBq} / \mathrm{mmol})$ were from NEN/DuPont (Dreieichenhain, F. R. G.). Inorganic chemicals and oestradiol-17 $\beta$ were from Merck (Darmstadt), and ampholines were from LKB (Sweden). The buffer for hormone receptor analysis contained $10 \mathrm{mmol} / 1 \mathrm{NaH}_{2} \mathrm{PO}_{4}, 10$ $\mathrm{mmol} / 1 \mathrm{Na}_{2} \mathrm{MoO}_{4} \cdot 2 \mathrm{H}_{2} \mathrm{O}, 115 \mathrm{ml} / \mathrm{l}$ glycerol $(87 \%), 1.5 \mathrm{mmol} / \mathrm{l}$ EDTA and $10 \mathrm{ml} / 1 \mathrm{monothioglycerol}(100 \%) ; \mathrm{pH}=7.4$.

\section{Preparation and incubation of cytosols}

After snap freezing in liquid nitrogen, tissues were pulverized by three passages through a microdismembrator (Braun, Melsungen) with intermediate cooling in liquid nitrogen. The tissue powder was slurried in $5-10$ volumes of buffer $(\mathrm{mg}+\mu \mathrm{l})$ and centrifuged in a Kontron TGA ultracentrifuge in a TST 60.4 swing-out rotor at $144000 \mathrm{~g}$. The supernatant was carefully trimmed of fat and pooled as cytosol. Protein was determined in $10 \mu \mathrm{l}$ of cytosol (23) using human serum albumin as standard.

Cytosols $(100 \mu \mathrm{l})$ were incubated for the single label assays with final concentrations of either $5 \mathrm{nmol} / 1$ [ $\left.{ }^{3} \mathrm{H}\right]$ oestradiol or [ $\left.{ }^{3} \mathrm{H}\right] \mathrm{ORG} 2058$, and for the double label assays with mixtures of either $5 \mathrm{nmol} / \mathrm{l}\left[{ }^{3} \mathrm{H}\right.$ ]oestradiol and $5 \mathrm{nmol} / 1$ [125 I]vinylnortestosterone or $5 \mathrm{nmol} / \mathrm{l}\left[16 \alpha_{-}{ }^{125} \mathrm{I}\right]$ oestradiol and $5 \mathrm{nmol}\left[{ }^{3} \mathrm{H}\right]$ ORG 2058. In some control experiments, a 200-fold molar excess of either unlabeled ORG 2058 or oestradiol was added. All test tubes were incubated for $2 \mathrm{~h}$ at $4^{\circ} \mathrm{C}$. After incubation, $100 \mu l$ supernatant were transferred to an isoelectric focussing gel, in order to separate bound, unbound and unspecifically bound hormone.

\section{Preparation and incubation of sections}

Duplicate sets of cryostat sections $(30 \mu \mathrm{m})$ to give a final section area of about $1 \mathrm{~cm}^{2}$ were collected on small glass coverslips and gently crushed into glass tubes containing $360 \mu \mathrm{l}$ of the buffer. To mimic a cytosol preparation with cryostat sections the sections were extracted for $2 \mathrm{~h}$ in the hypotonic medium, centrifuged at $800 \mathrm{~g}$, the supernatants incubated and the receptors separated and determined as described for cytosols. Protein was determined in $50 \mu \mathrm{l}$ supernatant (23).

\section{Isoelectric focussing}

Specifically bound, unbound and unspecifically bound fractions of hormone were separated by isoelectric focussing of $2 \mathrm{~mm}$ thick polyacrylamide gels using a horizontal electrophoresis chamber. Each gel had a final volume of $60 \mathrm{ml}$ and contained $48.5 \mathrm{~g} / \mathrm{l}$ acrylamide (Merck, Darmstadt), $1.5 \mathrm{~g} / \mathrm{l}$ bisacrylamide (Merck, Darmstadt), $115 \mathrm{ml} / 1$ glycerol $(87 \%), 15 \mathrm{ml} / 1$ ampholines $\mathrm{pH}=3-10$ and $10 \mathrm{ml} / \mathrm{l}$ ampholines $\mathrm{pH}=5-8$ (both LKB, Sweden). Polymerization was started by the addition of $180 \mu \mathrm{l}$ of ammonium peroxodisulphate $(100 \mathrm{~g} / \mathrm{l})$. The following solutions were used in the electrode compartments: cathode, $1 \mathrm{~mol} / 1$ sodium hydroxide; anode, $25 \mathrm{mmol} / 1$ aspartic acid and glutamic acid.
Samples $(100 \mu \mathrm{l})$ were pipetted into preformed slots near the cathodic electrode strip. Isoelectric focussing was performed on a cooling plate at $0{ }^{\circ} \mathrm{C}$ using a multiphor instrument (LKB, Sweden). The gel was prefocussed until reading $100 \mathrm{~V}(30-45$ min) using a constant current of $10 \mathrm{~mA}$. After sample application, the gel was focussed until reading $200 \mathrm{~V}$ (30-60 min), then a constant current was set at $15 \mathrm{~mA}$ with a limiting power setting of $18 \mathrm{~W}$ to avoid heating of the gel. The focussing gel was run until reading $1250-1300 \mathrm{~V}$ (approx. another 30 min). At the end of the run the gel was fractioned manually. First the gel was cut into sample-containing strips. These were cut into $3 \mathrm{~mm}$ pieces beginning at the alkaline side of the gel and ending at the acidic side. These $3 \mathrm{~mm}$ pieces were then transferred into microvials containing $4 \mathrm{ml}$ Xylofluor liquid scintillation cocktail (Baker, Holland). Gel slices were extracted for $45 \mathrm{~min}$ at $50^{\circ} \mathrm{C}$ and radioactivity was determined in a Rackbeta liquid scintillation counter (LKB, Sweden).

\section{Counting and evaluation}

In contrast to Pollow et al. (22), we did not perform an external standardisation, but used instead the auto-window-setting mode of the beta-counter for $\left.\left[{ }^{3} \mathrm{H}\right] /{ }^{125} \mathrm{I}\right]$ double label counting (Rackbeta; LKB, Sweden). In this mode the counter defines two energy windows of the beta-spectrum, in which a sample will be counted. In addition, an internal programme for automatic quench compensation ensures the adaptation of the energy windows according to the quenched amount of counts of an external standard superimposed on the radioactive sample.

\section{Calculation of results}

In this counting mode the counter defines the energy windows (channel 1 and 2) according to the respective beta-spectrum for each sample individually, and according to the counts in a channel after their adaptation by the internal quench compensation. In this way the ratio of iodine counts in the low energy part of the spectrum (channel 1) and in the high energy part of the spectrum (channel 2) is constant and in the range of the activity used, independent of the concentration of the $\left.{ }^{125} \mathrm{I}\right]$ iodine source used (fig. 1). In addition, the tritium counts in the high energy part of the spectrum is $1 \%$ or below. Therefore, the $\left[{ }^{125} \mathrm{I}\right]$ iodine can be quantitated directly in channel two (high energy part of the beta-spectrum). The efficiency determined for the total $\left[{ }^{125}\right.$ ] ]iodine activity in this channel was $30 \%$. The repeatedly determined ratio of ${ }^{125}$ I] $]$ iodine counts in channel 1 versus those in channel 2 was 1.56. The tritium counts in the low energy part of the spectrum were determined mathematically by programming the counter with a formula for correction of the total counts measured in channel 1:

counts $/ \min \left[{ }^{3} \mathrm{H}\right]=$ counts $/ \min$ channel $1-(1.56 \times$ counts/min channel 2)

The determined counting efficiency of tritium in channel 1 was $67.8 \%$.

Finally, graphs of radioactivity versus slice number were drawn for each sample and the cumulative height of the points in a single peak attributable to receptor-bound hormone was measured above a diagrammatic baseline, which was introduced with the computer from the minimum preceeding the peak to the minimum following the peak. This procedure gives similar results to those obtained using a baseline determined experimentally in the presence of a 200 -fold molar excess of unlabelled hormone (18). The amount of hormone whithin this peak was calculated and the result finally expressed in $\mathrm{fmol} / \mathrm{mg}$ supernatant protein. 


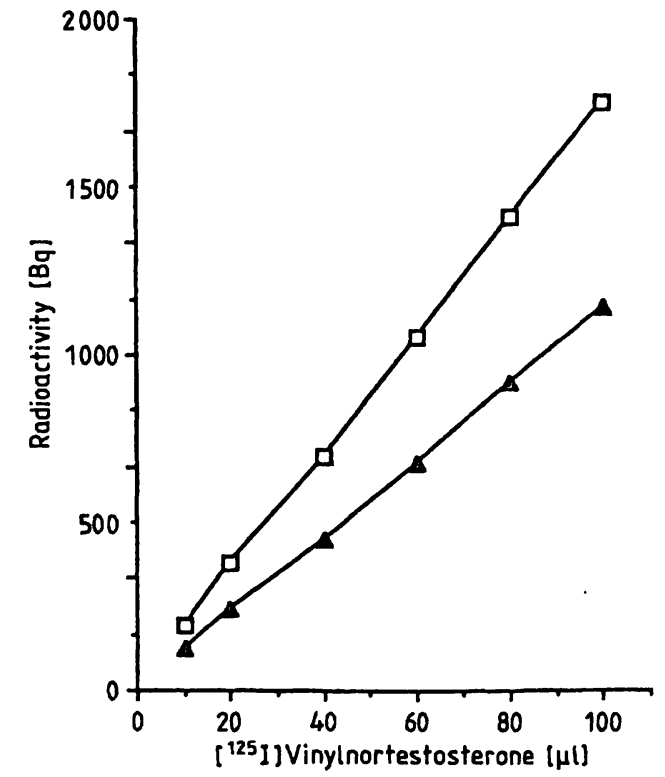

Fig. 1. Increasing amounts of a solution containing $\left[{ }^{125} \mathrm{I}\right]$ vinylnortestosterone $(5 \mathrm{nmol} / \mathrm{l})$ were diluted to 100 $\mu \mathrm{l}$, added to $5 \mathrm{ml}$ of scintillation fluid (Xylofluor, Baker, Holland) and counted simultaneously in two channels

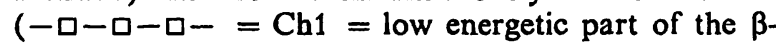
spectrum; $-\Delta-\Delta-\Delta-=C h 2=$ high energy part of the $\beta$-spectrum); for further details see methods.

\section{Results}

Resolution of oestrogen receptor and progesterone receptor molecules

Both receptors are clearly separated from unbound hormone and unspecifically bound hormone, determined in the presence of a 200 -fold molar excess of unlabelled hormone (18). Furthermore, after isoelectric focussing and counting, both receptor peaks are clearly resolved in a single assay, irrespectively of the combinations of hormones used. In figure 2 the resolution of $\left[{ }^{125} \mathrm{I}\right]$ vinylnortestosterone from $\left[{ }^{3} \mathrm{H}\right] \mathrm{oe}-$ stradiol (fig. 2a) and $\left[{ }^{125} \Pi\right]$ oestradiol from $\left[{ }^{3} \mathrm{H}\right] \mathrm{ORG}$ 2058 (fig. 2b) is shown in a single piece of tissue. For comparison, figures $2 \mathrm{c}$ and $2 \mathrm{~d}$ demonstrate the receptor peaks obtained in the single label assays with $\left[{ }^{3} \mathrm{H}\right]$ oestradiol and $\left[{ }^{3} \mathrm{H}\right] \mathrm{ORG} 2058$ of the same sample. The broad shape of the oestrogen receptor peak is not due to ineffective resolution of receptor molecules, but due to the omission of the limited trypsination procedure for the oestrogen receptor, to avoid digestion of progesterone receptor molecules (18).

\section{Assays with cytosols}

As a first step and as a prerequisite for the section assay, we checked the double label assay in tumour cytosols of human mammary carcinomas. We compared the receptor levels obtained by this assay with receptor levels determined in the single label assay with the same cytosol. As shown in figure 3 for the combination $\left[{ }^{125} \mathrm{I}\right]$ vinylnortestosterone $/\left[{ }^{3} \mathrm{H}\right]$ oestradiol, correlation coefficients of $r=0.97$ (fig. $3 a, n=37$, slope $=0.877$ ) were found for the gestagenic components, and $r=0.93$ (fig. $3 b, n=38$, slope $=0.742$ ) for oestradiol. Using the mixture of $\left[{ }^{125} \mathrm{I}\right]$ oestradiol and $\left[{ }^{3} \mathrm{H}\right]$ ORG 2058 , the correlations were $r=0.97$ (fig. $3 \mathrm{c}, \mathrm{n}=20$, slope $=0.741$ ) for the oestrogen receptor determinations and $r=0.88$ (fig. $3 \mathrm{~d}, \mathrm{n}=23$, slope $=1.127$ ) for the progesterone receptor assay.

Simultaneous determinations of oestrogen receptor and progesterone receptor in supernatants from sections

The results described above encouraged us to perform the assay with frozen sections of human endometrial tissue. The results of the comparative experiments are illustrated in figure 4. In general, we found a slightly poorer correlation in section supernatants than in cytosols. For the hormone combination $\left[{ }^{125} \mathrm{I}\right]$ vinylnortestosterone $/\left[{ }^{3} \mathrm{H}\right]$ oestradiol, we found a correlation of $r=0.81$ (fig. $4 a, n=18$, slope $=1.102$ ) for progesterone receptor, and $r=0.8$ (fig. $3 b, n=21$, slope $=0.607$ ) for oestrogen receptor determinations. For the combination $\left[{ }^{125} \mathrm{I}\right]$ oestradiol $/\left[{ }^{3} \mathrm{H}\right] \mathrm{ORG} 2058$ they were $r=0.82$ (fig. $3 c, n=23$, slope $=1.038$ ) for oestrogen receptor, and $\mathrm{r}=0.9$ (fig. $3 \mathrm{~d}, \mathrm{n}=23$, slope $=1.032$ ) for progesterone receptor.

In summary, the values determined with the iodine label, which are determined directly, correlate better than those measured with the tritiated hormone, which in part is calculated indirectly by a mathematical transformation of data of the lower part of the beta-energy spectrum. The exception is the determination of $\left[{ }^{3} \mathrm{H}\right] \mathrm{ORG} 2058$.

\section{Discussion}

We have established the double isotope assay for the determination of steroid hormone receptors in extracts from cryostat sections. As a first step, we adapted double isotope methods for simultaneous receptor determination in cytosols $(19-22)$ to a cytosolic assay with isoelectric focussing for receptor quantitation. The results were comparable to those described in the literature (19-22). In a second step, this method was used in the analysis of the receptor content in supernatants from frozen sections. During both steps the dual label assay was checked against the respective single label assay performed in parallel. 

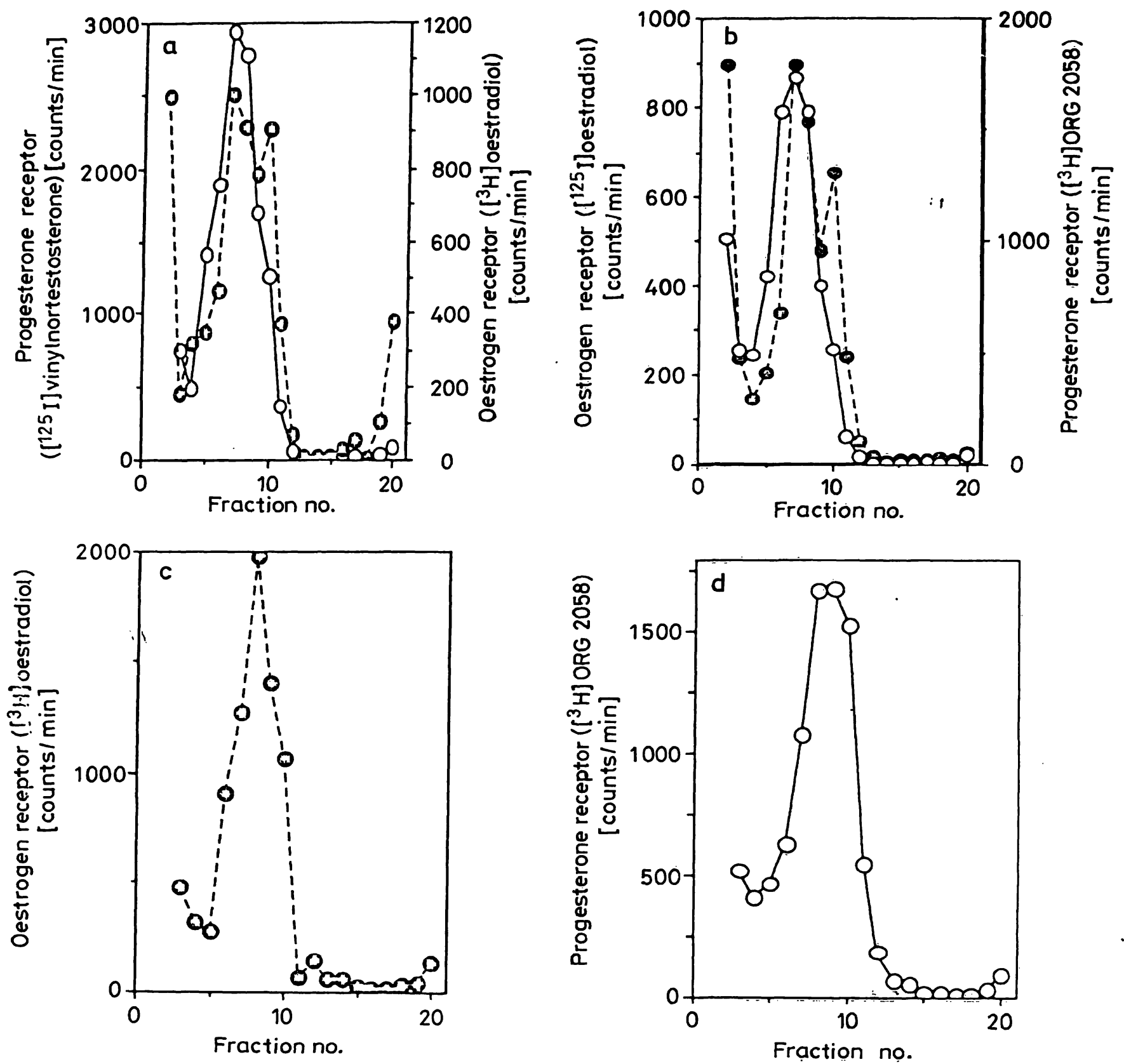

Fig. 2. The simultaneous representation of oestrogen receptor and progesterone receptor after isoelectric focussing of the supernatant of a single incubation mixture. The oestrogenic component is represented by solid circles and dashed line (-----), the gestagenic ligand by open circles and solid line (-0-0-).

a) Resolution of $\left[{ }^{125}\right]$ vinylnortestosterone and $\left[{ }^{3} \mathrm{H}\right]$ oestradiol.

b) Resolution of $\left[{ }^{125}\right.$ ] $]$ oestradiol and $\left[{ }^{3} \mathrm{H}\right] \mathrm{ORG} 2058$.

c) and d) The corresponding single label assays with $\left[{ }^{3} \mathrm{H}\right]$ oestradiol and $\left[{ }^{3} \mathrm{H}\right] \mathrm{ORG} 2058$ are illustrated.

From our results we favour the combination [ $\left.{ }^{125} \mathrm{I}\right]$ oestradiol $/\left[{ }^{3} \mathrm{H}\right] \mathrm{ORG} 2058$ for both the analysis of cytosols and sections. This combination is to be preferred, although, with one exception, the correlation coefficients are slightly poorer than in the $\left[{ }^{125} \mathrm{I}\right]$ vinylnortestosterone $/\left[{ }^{3} \mathrm{H}\right]$ oestradiol experiments. But with a single exception, the slopes of the regression lines for the plots of values from cytosolic and section experiments shown are approximately unity.
For $\left[{ }^{3} \mathrm{H}\right]$ oestradiol, the slope of the regression line in the parallel determination to $\left[{ }^{125} \mathrm{I}\right]$ vinylnortestosterone was 0.661 .

The advantages and disadvantages of the assay system described here can be listed as follows.

1. The assay is less expensive than the comparative single radiolabel assay and immunocytochemical assays: 

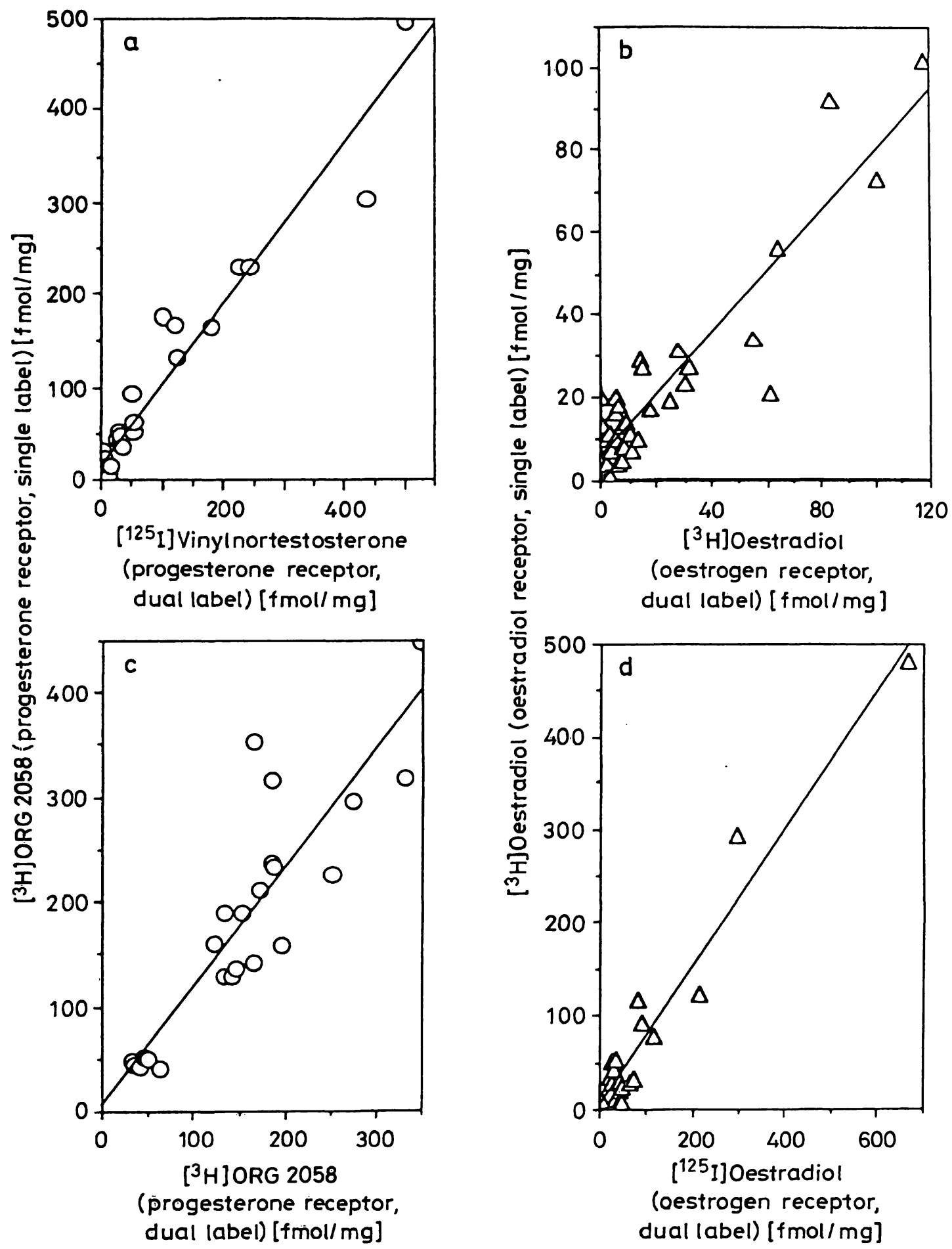

Fig. 3. Cytosol assays. Comparison of receptor concentrations obtained in single and double label experiments with cytosols.

a) Progesterone receptor measured with [ $\left.{ }^{125} \mathrm{I}\right]$ vinylnortestosterone (dual label assay) and [ $\left.{ }^{3} \mathrm{H}\right]$ oestradiol (single label assay).

b) Oestrogen receptor measured with $\left[{ }^{3} \mathrm{H}\right]$ oestradiol in both single and double label assay.

c) Oestrogen receptor measured with ${ }^{125}$ ] $]$ oestradiol (double label assay) and $\left[{ }^{3} \mathrm{H}\right]$ oestradiol (single label assay).

d) Progesterone receptor measured with $\left[{ }^{3} \mathrm{H}\right] \mathrm{ORG} 2058$ in both single and dual label assay.

2. The amount of tissue (18) again has been further reduced by one half. Therefore, the assay can be performed with a quantity of tissue similar to that used in immunocytochemical procedures.

3. The final result is a quantitative measurement of receptor concentrations ( $\mathrm{fmol} / \mathrm{mg}$ ) and not a semiquantitative score of labelled cells.
4. The receptors are determined in the same set of frozen sections.

5. Histological controls or histochemical localizations of the receptors can be made in immediately neighbouring serial sections.

6. The receptors are separated in a single step from unbound and unspecifically bound hormone. The re- 

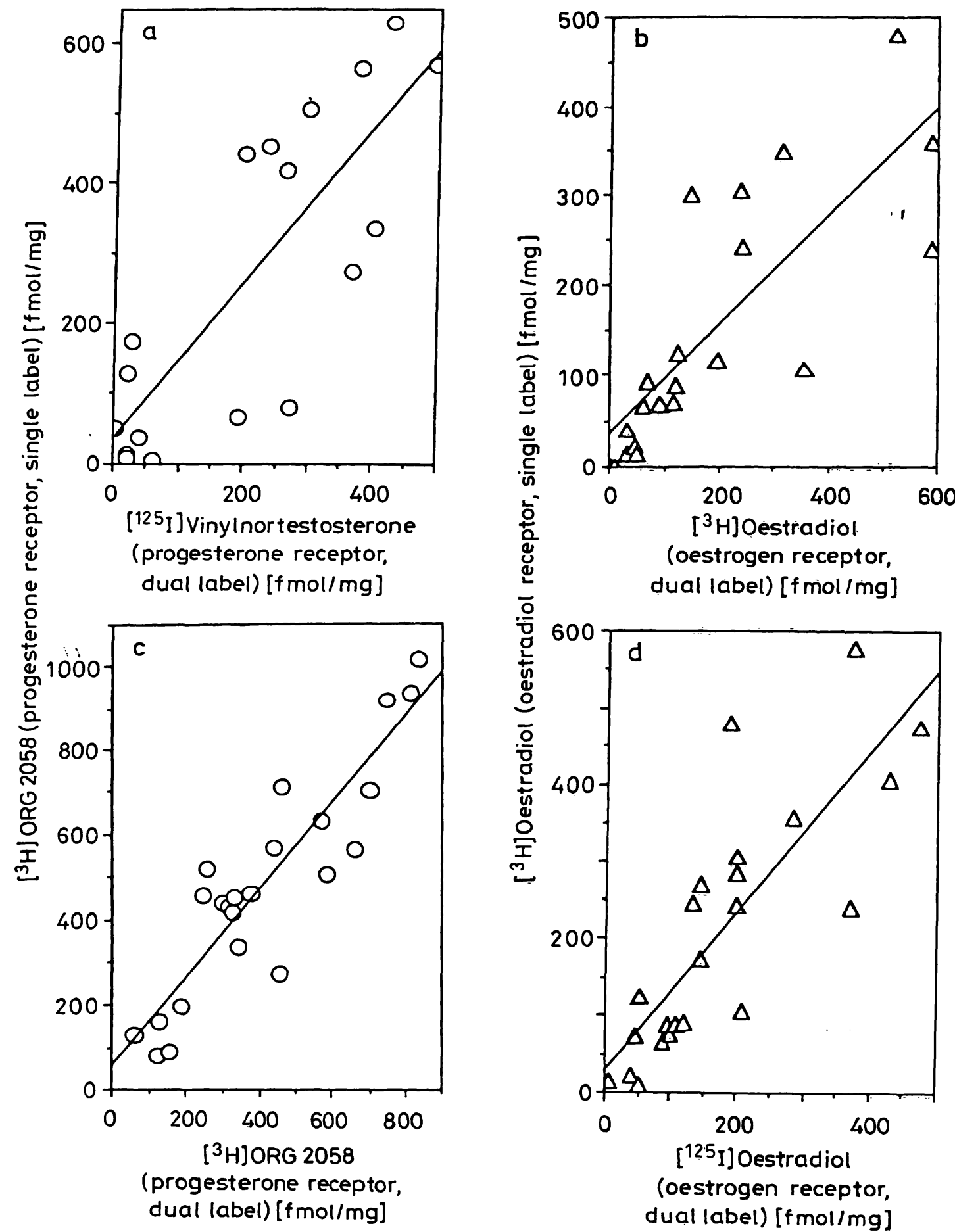

Fig. 4. Section assays: Comparison of oestrogen receptor and progesterone receptor concentrations measured in single and double label assays with section supernatants. The results for progesterone receptor (a) and oestrogen receptor (b), measured simultaneously with [ $\left[{ }^{125}\right]$ vinylnortestosterone and $\left[{ }^{3} \mathrm{H}\right]$ oestradiol, or in single label assays with $\left[{ }^{3} \mathrm{H}\right] \mathrm{ORG} 2058$ and $\left[{ }^{3} \mathrm{H}\right.$ ] $]$ oestradiol, are compared. For the experiments illustrated in c) and d) the combination of [ $\left[{ }^{125} \mathrm{I}\right]$ oestradiol and $\left[{ }^{3} \mathrm{H}\right] \mathrm{ORG}$
2058 was used.

sulting peak pattern of oestrogen receptor and progesterone receptor serve as an additional quality control of the assay, and as described recently (18) receptor concentrations measured by isoelectric focussing are always higher than with the standard dextrancoated charcol (DCC) assay.

However, one disadvantage cannot be concealed. The separation step by isoelectric focussing makes this assay more time consuming than other assays. However, this procedure is necessary to concentrate receptor molecules in the rather dilute extracts of sections.

In conclusion, with respect to the amount of tissue needed, the described assay system is' a biochemical alternative to immunocytochemical procedures, and it provides concentrations of receptors as the final result. We feel that the method is especially useful 
1. when small specimens of mammary carcinomas have to be analysed biochemically for receptor content,

2. for research projects that simultaneously seek to determine receptor quantities and receptor localization.

The assay is equally well applicable to cells grown in culture, and is an important tool if the receptor content has to be determined in a small number of cells.

\section{Acknowledgement}

The authors wish to thank $M$. Kniewe and $W$. Wünsche for expert technical assistance and Dr. $P$. Ball for critical reading of the manuscript. This paper comprises the main parts of the dissertation of $B$. Helmchen.

\section{References}

1. Kauppila, A. \& Vihko, R. (1986) Estrogen and progestin receptors as prognostic markers in endometrial cancers. In: Endometrial Cancer (Schulz, K. D., King, R. J. B., Pollow, K. \& Taylor, R. W., eds.) pp. 104-111, Zuckschwerdt Verlag, München.

2. Smith, R. G. \& Sestili, M. A. (1980) Methods for ligand receptor assays in clinical chemistry. Clin. Chem. 26, 543550.

3. Leclerq, G. (1987) Technical pitfalls, methodological improvements and quality control of steroid hormone receptor assays. Europ. J. Canc. Clin. Oncol. 23, 453-458.

4. Greene, G. L., Nolan, C., Engler, J. P. \& Jensen, E. V. (1980) Monoclonal antibodies to human estrogen receptors. Proc. Natl. Acad. Sci. (Wash.) 77, 5115-5119.

5. Logeat, F., Hai, M. T. V., Fournier, A., Legrain, P., Buttin, G. \& Milgrom, E. (1983) Monoclonal antibodies to rabbit progesterone receptor: cross-reaction with other mammalian progesterone receptors. Proc. Natl. Acad. Sci. (U.S. A.) $80,6456-6459$.

6. Magdalenat, H., Merle, S. \& Zajdela, A. (1986) Enzyme immunoassays of estrogen receptors in fine needle aspirates of breast tumors. Cancer Research 46, 4265s-4267s.

7. Flowers, J. L., Cox, E. B., Geisinger, K. R., Burton, G. V., McCarthy, K. S. Sr., Mc Carthy, K. S. Jr. \& Dent, G. A. (1986) Use of monoclonal antiestrogen receptor antibody to evaluate estrogen receptor content in fine needle aspirate biopsies. Ann. Surg. 203, 250-256.

8. Greene, G. L., Sobel, N. B., King, W. J. \& Jensen, E. V. (1984) Immunocytochemical studies of estrogen receptors. J. Steroid Biochem. 20, 51-56.

9. Press, M. F., Udove, J. A. \& Greene, G. L. (1987) Progesterone receptor distribution in the human endometrium. Am. J. Pathol. 131, 112-124.

10. Perrot-Applanat, M., Logeat, F., Groyer-Piccard, M. T. \& Milgrom, E. (1985) İmmunocytochemical study of mammalian progesterone receptor using monoclonal antibodies. Endocrinology 116, 1473-1484.

11. Perrot-Applanat, M., Groyer-Picard, M. T., Lorenzo, F., Jolivet, A., Hai, M. T. V., Pallud, C., Spyratos, F. \& Milgrom, E. (1987) Immunocytochemical study with monoclonal antibodies to progesterone receptor in human breast cancer. Cancer Research 47, 2652 - 2661.

12. Pousette, A., Gustafsson, S. A., Thörnblad, A. M., Sällström, J., Lindgren, A., Sundelin, P. \& Gustafsson, J. A. (1986) Quantification of estrogen receptor in seventy-five specimen of breast cancer: comparison between an immunoassay (Abbott ER-EIA monoclonal) and ${ }^{3} \mathrm{H}$-estradiol binding assay based on isoelectric focusing in polyacrylamide gels. Cancer Research 46, 4308s-4309s.
13. Heubner, A., Beck, T., Grill, H. J. \& Pollow, K. (1986) Comparison of immunocytochemical estrogen receptor assays, estrogen receptor enzyme immunoassays, and radioligand-labeled estrogen receptor assay in human breast cancer and uterine tissue. Cancer Research 46, 4291s4295s.

14. Goussard, J., Lechevrel, C., Martin, P.-M. \& Roussel, G. (1986) Comparison of monoclonal antibodies and tritiated ligands for estrogen receptor assays in 241 cancer cytosols. Cancer Research 46, 4282s-4287s.

15. Underwood, J. C. E., Dangerfield, V. J. M. \& Parson, M. A. (1983) Estrogen receptor assay of cryostat sections of human breast carcinomas with simultaneous quantitative histology. J. Clin. Pathol. 36, 399-405.

16. DeGoeij, A. F. P. M., Vollberg, M. P. W., Hondius, G. G. \& Bosman, F. T. (1984) Radiochemical determination of estrogen receptors in cryostat sections of target tissues. J. Steroid Biochem. 21, 127-134.

17. DeGoeij, A. F. P. M., Scheres, H. M. E., Rousch, M. J. M., Hondius, G. G. \& Bosman, F. T. (1988) Progesterone receptor quantification with radiolabeled promegestone $(R$ 5020 ) in frozen sections of endometrium and breast cancer tissue. J. Steroid Biochem. 29, 465-474.

18. Vollmer, G., Bindewald, I., Meyn, U., Wünsche, W. O., Arnholdt, H. \& Knuppen, R. (1988) An improved micromethod for the determination of biochemically active estrogen and progesterone receptors in parallel to comparative histological examination of a single piece of tissue. J. Steroid Biochem. 31, 899-907.

19. Thibodeau, S. N., Freeman, L. \& Jiang, N.-S. (1981) Simultaneous measurement of estrogen and progesterone receptors in tumor cytosols with use of ${ }^{125} \mathrm{I}$-labeled estradiol and of ${ }^{3} \mathrm{H}-\mathrm{R} 5020$. Clin. Chem. 27, 687-691.

20. Grill, H. J., Manz, B. \& Pollow, K. (1982) Double labelling assay system for estrogen and progesterone receptors. Lancet $I, 1982,679$.

21. Grill, H. J., Manz, B., Belovsky, O. \& Pollow, K. (1984) Labelling assay for simultaneous determination of estrogen and progesterone receptors. Oncology 41, 25-32.

22. Pollow, K., Heubner, A., Grill, H. J., Beck, T. \& Manz, B. (1986) Present problems of steroid hormone receptor analysis in the tumor tissue. In: Endometrial Cancer (Schulz, K. D., King, R. J. B., Pollow, K. \& Taylor, R. W., eds.) pp. 52-66. Zuckschwerdt Verlag, München.

23. Bradford, M. M. (1976) A rapid and sensitive method for the quantitation of microgram quantities of protein utilizing the principle of protein-dye binding. Anal. Biochem. $72,248-254$.

Prof. Dr. Rudolf Knuppen

Institut für Biochemische Endokrinologie Medizinische Universität

Ratzeburger Allee 160

D-2400 Lübeck 
